\title{
Proteksi Hukum Pasien Dalam Pelayanan Kesehatan di Ruang Opname RSUD dr. Slamet Garut
}

\author{
Aceng Ali Awaludin ${ }^{1}$, Andhika Lungguh Perceka ${ }^{2}$
}

\begin{abstract}
Abstrak
Perlindungan hukum adalah hak untuk memperoleh keadilan, keteraturan, ketentuan, kegunaan, dan kenyamanan bagi hak-hak individu atau kelompok di mata hukum. Penelitian ini membahas tentang perlindungan hukum pasien ketika menerima layanan perawatan kesehatan di Rumah Sakit dr. Slamet Garut yang dikaji berdasarkan aturan perlindungan konsumen dan undang-undang kesehatan dengan tujuan untuk mengetahui bagaimana perlindungan hukum Pasien dan implementasinya dalam pelayanan kesehatan dan memenuhi hak-hak pasien oleh tenaga kesehatan dan rumah sakit. Teknik yang digunakan deskriptif kuantitatif, analisis univariat, jumlah sampel 97 responden, data diambil menggunakan lembar pertanyaan dan hasilnya menunjukkan bahwa sebagian besar responden $(66,0 \%)$ Perlindungan hukum pasien terpenuhi dan hampir setengah responden $(34,0 \%)$ Perlindungan hukum pasien tidak terpenuhi. Harus ada strategi atau upaya dari rumah sakit untuk lebih meningkatkan aspek perlindungan hukum pasien untuk mendapatkan layanan yang tepat bagi pasien, sehingga perlindungan hukum pasien dapat terpenuhi sepenuhnya
\end{abstract}

Kata Kunci: Perlindungan hukum, pasien, layanan kesehatan.

\section{Abstract}

Legal protection is the right to acquire justice, regularity, provision, usefulness and convenience to the rights of individuals or groups in the eyes of the law. This research discusses the protection of the patient's law when receiving health care services in Dr. Slamet Garut Hospital which is studied at the rules of consumer protection and health legislation with the aim to know how the legal protection Patients and their implementation in healthcare services and fulfilling the rights of patients by health and hospital personnel. Techniques used quantitative descriptive, univariate analysis, sample number 97 respondents, data was taken using a question sheet and the results showed that most of the respondents (66.0\%) Patient's legal protection is fulfilled and nearly half the respondent (34.0\%) Patient legal protection is not met. There should be a strategy or effort from the hospital to further improve the legal protection aspect of the patient in order to obtain appropriate services to the patient, so that the patient's legal protection can be fully fulfilled.

Keywords: legal protection, patient, health service.

\section{PENDAHULUAN}

Usaha peningkatan kualitas

kesehatan baik fisik dan non fisik masyarakat diperlukan kerjasama antara pemerintah, swasta, dan perguruan tinggi dalam pembangunan dibidang kesehatan. Kesehatan itu sendiri berarti kondisi fisik, psikis dan sosial masyarakat yang berjalan baik serta bebas dari penyakit (WHO, 2010).

Sebagai penyedia jasa layanan kesehatan baik secara individu maupun organisasi, rumah sakit memberikan 
layanan kegawatdaruratan, berobat jalan, opname dan perawatan serta pemulihan berikut segala penunjangnya yang diperuntukan untuk untuk kepentingan masyarakat dalam meningkatkan kualitas hidup. Usaha peningkatan kualitas kesehatan baik fisik dan non fisik masyarakat diperlukan kerjasama antara pemerintah, swasta, dan perguruan tinggi dalam pembangunan dibidang kesehatan. Kesehatan itu sendiri berarti kondisi fisik, psikis dan sosial masyarakat yang berjalan baik serta bebas dari penyakit (WHO, 2010).

Sebagai penyedia jasa layanan kesehatan baik secara individu maupun organisasi, rumah sakit memberikan layanan kegawatdaruratan, berobat jalan, opname dan perawatan serta pemulihan berikut segala penunjangnya yang diperuntukan untuk untuk kepentingan masyarakat dalam meningkatkan kualitas hidup.

Tenaga kesehatan di era digital ini perlu dibekali dengan pemahaman dan kompetensi akan penggunaan alat-alat kesehatan yang modern, sehingga teknologi tersebut dapat membantu mempercepat dan mempermudah tenaga medis dalam memberikan layanan kesehatan serta mampu mengurangi resiko yang tidak diinginkan karena kesalahan yang diakibatkan keselahan manusia (Pohan, 2015).
Meningkatnya kesadaran hukum masyarakat tentang hak dan kewajiban bagi seorang pasien dapat dilihat berdasarakan dari laporan kejadian atau berdasarkan kasus yang terjadi di masyarakat yang melibatkan pasien atau keluarga pasien dengan rumah sakit sebagai provider kesehatan. Kesadaran itu muncul karena ketidakpuasan keluarga dan pasien atau merasa dirugikan oleh pelayanan di rumah sakit, sehingga kepercayaan masyarakat terhadap dunia medis menjadi berkurang dan pasien harus lebih berhati-hati, mengawasi dan bertanya ketika tenaga medis memberikan tindakan atau pelayanan kesehatan sehingga tidak terjadi kesalahan dan kelalaian oleh tenaga kesehatan (Nurdin, 2015).

Bentuk proteksi diri sebagai seorang konsumen dibutuhkan sikap dan perilaku yang bertanggung jawab serta meningkatkan kesadaran, pengetahuan, rasa peduli dan tidak bergantung pada orang lain, sehingga meningkatkan derajat dan harga diri konsumen (Nasution, 2017). Sebagai penerima manfaat dari layanan kesehatan Pasien wajib dilindungi hakhaknya dan dijamin kesehatannya dalam bentuk aturan dan perundangan yang berlaku dimasyarakat. Dengan adanya undang-undang atau aturan bukan merupakan jaminan bahwa di instansi pelayanan kesehatan tidak akan terjadi kesalahan atau malparktik, akan tetapi meminamalisir atau menghindari adanya 
permasalahan yang merugikan pasien. Adapun ketidakpuasan atau kerugian yang di alami pasien dalam pelayanan adalah malpraktik yang di lakukan oleh tenaga kesehatan. Walaupun hak-hak pasien sudah di lindungi dengan undang-undang tetapi tidak menjamin bahwa tidak akan ada permasalahan bahkan disetiap tahun masalah yang merugikan pasien semakin bertambah (Siringoringo, Hendrawati and Suharto, 2017).

Setiap warga negara indonesia memiliki harapan untuk hidup secara layak, damai, aman dilingkungan yang sehat (Indonesia, 2016). Upaya menjamin pemenuhan hak-hak akan proteksi, jaminan dan kepastian hukum dapat terlakasana dapat dengan baik khususnya dalam pelayanan bidang kesehatan dijamin oleh negara (Presiden RI, 2009).

Kesejahteraan merupakan salah satu harapan masyarakat dalam pemenuhan kebutuhan akan kesehatan yang memerlukan suport hukum bagi pengelolaan kesehatan. Pelayanan kesehatan yang semula hanya berupa kuratif dan rehabilitatif sekarang berkembang menjadi pembangunan kesehatan yang utuh, sistematis, dan berkelanjutan untuk meningkatan, mencegah dan menyembuhkan serta memulihkan dalam upaya peningkatan kesehatan (Kep, Kep and Purdiyani Bagian Pendidikan Kesehatan dan Ilmu Perilaku, 2015).
Adapun faktor yang mempengaruhi upaya penyelenggaraan kesehatan yaitu faktor lingkungan, kemasyarakatan dan tradisi, ekonomi, lingkungan fisik dan bilogis yang bersifat berubah-ubah dan rumit. Untuk mendapatkan standar kesehatan yang optimal pemerintah berusaha meningkatkan sarana dan fasilitas pelayanan kesehatan yang komprehensif, sistematis, adil dan terjangkau masyarakat.

Dalam mewujudkan indonesia sehat sebagai bentuk dukungan masyarakat dalam pembangunan kesehatan yaitu Profesionalisme tenaga kesehatan dalam memberikan pelayanan kesehatan sangatlah penting dalam menjaga kualitas pelayanan sehingga mempengaruhi kepuasan pasien di pusat pelayanan kesehatan (Perceka, 2018). Kepuasan pasien merupakan harapan yang diterima pasien setelah menerima layanan kesehatan setelah kebutuhan pasien terpenuhi (Nuryaasiinta, 2019).

Strategi pembangunan diranah kesehatan tersebut bertujuan dalam mengupayakan peningkatan mutu kesehatan, sehingga kualitas pelayanan kesehatan meningkat sehingga dibutuhkan standar kualitas pelayanan yang menyeluruh, terstruktur dan dapat di monitoring serta di evaluasi setiap bentuk pelayanannya agar pelayanan kesehatan menjadi baik.

Rumah sakit dr. Slamet Garut merupakan instansi kesehatan milik 
pemerintah kabupaten Garut terkareditasi

B. Sebagai pusat penanganan kesehatan yang lebih tinggi rumah sakit menerima pasien yang tidak bisa ditangani oleh puskesmas dan klinik di Kabupaten Garut. RSUD dr. Slamet Garut menetapkan standar aturan-aturan mengenai kebijakankebijakan tata tertib yang meliputi, tata tertib bagi pengunjung, pintu masuk dan pintu keluar rumah sakit, alur dan waktu distribusi pada instalasi gizi, laundry, sanitasi, CSSD dan kedokteran forensik. Serta penerapan hak-hak pasien dan proteksi yang diberikan kepada pasien guna memberikan pelayanan terbaik mereka kepada pasien.

Pasien atau pesakit merupakan orang yang mendapatakan tindakan perawatan. Pendapat lain pasien adalah subyek yang mengalami penderitaan (suffering) dan ketidaknyamanan yang berat yang mengancam keutuhan atau integritas seseorang (Black and Black, 2018).

Karakteristik seseorang sangat mempengaruhi pola kehidupan sesorang, karakteristik bisa dilihat dari beberapa sudut pandang diantaranya umur, jenis kelamin, tingkat ekonimi, pekerjaan, status perkawinan dan tingkat pendidikan seseorang. Kualitas hidup seseorang dipengaruhi oleh keseriusan sesorang dalam menjaga kesehatannya. (Budiarto \& Anggraeni, 2002 dalam colina T.S 2013).
Wewenang dan tanggungan orang sakit yaitu: menerima penjelasan aturan yang ada di rumah sakit, menerima keterangan akan hak dan kewajiban pasien, memperoleh kans jasa yang sama, menerima jasa kesehatan yang berkualitas sesuai dengan standar prosedur pelayanan, menerima layanan yang berdayaguna, mengajukan komplain pengaduan atas kualitas pelayanan yang diterima, ketujuh, bebas memilih dokter dan ruang perawatan sesuai dengan kemampuan, menghendaki temu muka dengan dokter lain tentang penyakit yang dialaminya (Undang-Undang Republik Indonesia Nomor 44, 2009).

Keterikatan antara dokter dan pasien adalah tolak ukur antara keseimbangan wewenang dan tanggungjab untuk mencapai suatu keadilan didalam suatu tindakan, antara maka hak yang satu harus diimbangi oleh kewajiban pihak yang lainnya, begitu juga dengan sebaliknya.

Interaksi antara dokter dan pasien dalam ilmu kedokteran berupa interaksi biomedis aktif dan pasif. Dokter sebagai tenaga profesional memberikan jasa sesuai dengan kompetensi, standar dan kode etik profesi dan pasien mendapatkan jasa kesehatan tersebut (Muhamad Sadi, 2015).

Daya upaya yang diusahakan perorangan atau kelompok dalam suatu organisasi untuk memajukan dan menjaga kesehatan melalui pencegahan, 
penyembuhan penyakit dan rehabilitasi kesehatan adalah pelayanan kesehatan (Muhamad Sadi, 2015).

Peran penting hukum dalam peningkatan pelayanan dalam memberikan jaminan keadilan dan proteksi bagi pasien di instansi pelayanan kesehatan, maka semakin besar peran hukum dalam menjalankan tanggungjawabnya.

Bagian yang berinteraksi pada setiap kegiatan pelayanan kesehatan di instansi pelayanana kesahatan, yaitu : dokter, perawat, bidan, dan apoteker. Kaitan hukum ditimbulkan akibat hubungan antara pasien dengan dokter dan tenaga kesehatan lain karena adanya ketidakpuasaan antara pasien dengan penyelenggara kesehatan atau dengan tenaga kesehatan hubungan pelayanan kesehatan (Muntaha, 2018).

Tindak lanjut rumah sakit untuk menjawab keluhan pasien diantaranya rumah sakit menyediakan kotak saran di setiap ruangan serta layanan pengaduan untuk menerima masukan dan komentar dari masyarakat. Respon terhadap ketidakpuasan masyarakat dilihat dari kesesuaian antara prosedur layanan dengan tindakan yang diberikan sehingga apabila jasa tidak sama dengan prosedur yang sudah ditetapkan, maka rumah sakit akan memperbaikinya.

Rumah Sakit dr Slamet Garut menerima pasien BPJS dan pasien non BPJS, sehingga pasien yang datang mendapat perlakuan yang sama dalam pelayanana, akan tetapi selalu ada kendala yang dikeluhkan oleh setiap pasien BPJS pelayanan kesehatan. Diantaranya mengeluhkan tentang prosedur perlayanan di rumah sakit yang rumit, petugas yang kurang ramah dan lamban, sehingga pasien dan keluarga tidak puas akan pelayanan yang ada.

Bersumber pada hasil pengamatan awal dengan dengan melakukan wawancara diruang opname RSUD dr. Slamet Garut, perawat dan mahasiswa praktik memaparkan sebelumnya pada tahun 2018 pernah terjadi kesalahan pemberian obat terhadap pasien tapi tidak ada tindakan yang dilakukan melainkan hanya menunggu apakah terjadi reaksi atau tidak kepada pasien. Kemudian pasien diantaranya menyatakan perawat melakukan kesalahaan saat melakukan penyuntikan infus sampai beberapa kali penyuntikan sehingga menyebabkan pembengkakan. Dari permasalahan diatas peneliti tertarik menelaah lebih lanjut tentang proteksi hukum bagi pasien di ruang opname RSUD dr Slamet Garut dalam pelayanan kesehatan.

Konsep Proteksi hukum dalam bahas Inggris disebut legal protection, yaitu proteksi kepada seluruh warga negara Indonesia dapat berupa proteksi secara dan mendapatkan perlakuan yang sama di mata hukum. Proteksi wujud merupakan proteksi yang wujud suatu 
benda atau barang. Sedangkan proteksi hukum yaitu proteksi akan kewenangan setiap warga Negara (Muntaha 2018).

Media proteksi hukum ada dua macam, yaitu media proteksi hukum melalui pencegahan dan media proteksi hukum melalui penyelesaian sengketa. Dasar proteksi hukum bagi orang yang sakit merupakan jaminan kepastian hukum berupa proteksi kepada orang sakit dalam mendapatkan jasa kesehatan yang sesuai standar pelayanan. Dua hal yang dapat menjadi penghambat atau pendukung pelaksanaan proteksi hukum pasien yaitu faktor dari dalam yang menjadi pendukung berupa komunikasi, data dan tenaga kesehatan. faktor dari luar yang menjadi pendukung Motivasi pasien, dan kepatuhan pasien.

Adapun faktor penghambat proteksi pasien dari dalam yaitu Komunikasi yang kurang antara pasien dan tenaga kesehatan, sarana medis yang tidak representataive dan suasana kerja yang kurang baik dan faktor penghambat dari luar yaiitu sikap pesimis pasien (Gde Muninjaya, 2014).

\section{METODE PENELITIAN}

Desain penelitian yang digunakan yaitu deskriptif kuantitatif dengan menggunakan variabel tunggal yaitu proteksi hukum pasien dalam pelayanan kesehatan dengan sampel sebanyak 97 orang yaitu pasien yang sedang menerima asuhan keperawatan di Ruang opname
RSUD dr. Slamet Garut dengan metode non probability sampling secara quota sampling. Data diambil pada bulan Maret 2019 di ruang opname RSUD dr Slamet Garut dengan membagikan kuesioner kepada pasien. Data yang terkumpul diolah dengan dilakukan pemeriksaan data, pemberian kode, memasukan data, dan pengecekan kembali data.

Sesuai dengan rumusan masalah bahwa fokus penelitian ini adalah proteksi hukum pasien dalam pelayanan kesehatan diruang opname RSUD dr Slamet Garut. Fokus penelitian yaitu proteksi hukum pasien saat menerima jasa kesehatan di rumah sakit dr. Slamet Garut yang dikaji bersumber pada aturan Proteksi Konsumen dan perundang-undangan kesehatan dengan tujuan untuk mengetahui bagaimanakah proteksi hukum pasien dan implementasinya dalam pelayanan kesehatan serta terpenuhinya hak-hak pasien oleh tenaga kesehatan dan rumah sakit.

\section{HASIL DAN PEMBAHASAN}

\section{Hasil Penelitian}

a. Karakteristik Pasien di Ruang Opname RSUD dr. Slamet Garut

Tabel 1. Sebaran Data Karakteristik Pasien di Ruang opname RSUD dr. Slamet Garut 


\begin{tabular}{lcc}
\hline \multicolumn{1}{c}{$\begin{array}{c}\text { Karakteristik } \\
\text { Pasien }\end{array}$} & F & \% \\
\hline Jenis Kelamin & & \\
Perempuan & 50 & 51.5 \\
Laki-laki & 47 & 48.5 \\
Usia & & \\
12-16 Tahun & 1 & 1 \\
17-25 Tahun & 18 & 18.6 \\
26-35 Tahun & 21 & 21.6 \\
36-45 Tahun & 31 & 32 \\
46-55 Tahun & 14 & 14.4 \\
56-65 Tahun & 10 & 10.3 \\
>65 Tahun & 2 & 2.1 \\
Pendidikan & & \\
Pendidikan Dasar & 1 & 1 \\
Pendidikan & 40 & 41.2 \\
Menengah & 14 & 14.4 \\
Pendidikan Atas & 33 & 34 \\
Vokasi & 5 & 5.2 \\
S1 & 5 & 5.2 \\
Pekerjaan & & \\
Tidak Bekerja & 18 & 18.6 \\
Petani & 16 & 16.5 \\
IRT & 33 & 34 \\
Wiraswasta & 28 & 28.9 \\
PNS/TNI/POLRI & 2 & 2.1 \\
& & \\
\hline & & \\
& &
\end{tabular}

Bersumber pada Tabel 1, diketahui (51.5\%) responden Perempuan, (32.0\%) responden dewasa akhir, (1.0\%) remaja awal, (41.2\%) responden $\mathrm{SD},(1.0 \%)$ responden Tidak sekolah, (34.0\%) responden IRT, dan $(2.1 \%)$ responden PNS/TNI/POLRI.

b. Tingkat Proteksi Hukum Pasien di Ruang Opname RSUD dr. Slamet Garut

Tabel 2. Sebaran data Proteksi Hukum Pasien di Ruang Opname RSUD dr. Slamet Garut

\begin{tabular}{|c|c|c|}
\hline \multirow{2}{*}{\multicolumn{3}{|c|}{$\begin{array}{c}\text { Kategori } \\
\text { Proteksi }\end{array}$}} \\
\hline & & \\
\hline - $\quad$ Tidak & 33 & 34 \\
\hline Terpenuhi & 64 & 66 \\
\hline $\begin{array}{ll}\text { - } & \text { Terpenuhi } \\
\text { Jumlah }\end{array}$ & 97 & 100 \\
\hline
\end{tabular}

Bersumber pada tabel 2 diketahui bahwa $(66.0 \%)$ responden terpenuhi dan $(34.0 \%)$ responden tidak terpenuhi

\section{Pembahasan}

Hasil penelitian tingkat karakteristik, diketahui bahwa hampir setengahnya responden (32.0\%) Dewasa akhir, Dan sebagian kecil dari responden (1.0\%) Remaja awal, dan diketahui lebih dari setengahnya responden $(51.5 \%)$ Perempuan, dan diketahui bahwa hampir setengahnya responden (41.2\%) SD, dan sebagian kecil dari responden (1.0\%) Tidak sekolah, dan diketahui bahwa hampir setengahnya responden $(34.0 \%)$ IRT, dan PNS/TNI/POLRI (2.1\%) responden. Penelitian tingkat proteksi hukum pasien diketahui bahwa (66.0\%) responden proteksi hukum terpenuhi dan $(34.0 \%)$ responden Tidak terpenuhi. Hasil penelitian di atas menunjukan bahwa proteksi hukum terhadap pasien $(66.0 \%)$ responden terpenuhi, sehingga pasien dalam mendapatkan pelayanan kesehatan mendapatkan proteksi hukum sudah sesuai dengan perundangan. Proteksi hukum merupakan upaya proteksi hak-hak bagi masyarakat diatur dalam peraturan atau perundangan yang berlaku (Syafruddin and Anand, 2015).

Proteksi hukum terhadap pasien merupakan faktor penting dalam sebuah pelayanan kesehatan, hal ini sependapat dengan penelitian lain bahwa proteksi hukum terhadap pasien erat kaitannya 
dengan adanya kepatuhan akan standar prosedur oleh petugas kesehatan sehingga menghindari resiko kesalahan dalam penanganan, tindakan dan pelayanan kesehatan. (Ni Luh Gede Yogi Arthani, S.H., M.H., Made Emy Andayani Citra, S.H., 2013).

Walaupun demikian kepuasan pasien terhadap pelayanan di rumah sakit menjadi tolak ukur pelayanan, pada kenyataannya masih terdapat kasus dan tanggung gugat akibat pasien ketidakpuasan pasien yang melibatkan rumah sakit sehingga mengindikasi bahwa meningkatnya pemahaman hukum di masyarakat. Apabila pemahaman hukum meningkat, maka masyarakat semakin paham akan haknya sebagai pasien dan semakin tinggi pula hukum melakonkan tugasnya di bidang kesehatan (Nurdin, 2015).

Dalam pelaksanaan pemberian layanan kesehatan hak-hak pasien dilindungi oleh perundang-undangan. Namun pada kenyataan dilapangan masih terdapat permasalahan yang menyebabkan ketidakpuasan dan merugikan pada pasien $(34.0 \%)$ responden tidak terpenuhi. Peristiwa ini dapat disebabkan oleh keteledoran, kurangnya tanggung jawab dan profesionalisme dari tenaga kesehatan. Malpraktik adalah bentuk kerugian yang dialami pasien yang diakibatkan kesalahan tindakan dan ketidak hati-hatian oleh penyelenggara atau petugas kesehatan (Sibarani, 2017)..

\section{KESIMPULAN DAN SARAN}

\section{Kesimpulan}

Proteksi hukum pasien merupakan salah satu bentuk pemberdayaan masyarakat yang merupakan bagian dari kesejahteraan bagi pasien, RSUD $\mathrm{dr}$ Slamet Garut yang merupakan salah satu rumah sakit milik pemerintah menetapkan standar aturan-aturan mengenai kebijakankebijakan tata tertib serta penerapan hakhak pasien dan perlindungan yang diberikan kepada pasien guna memberikan pelayanan terbaik mereka kepada pasien.

Berdasarkan hasil penelitian yang telah dilakukan mengenai Gambaran Perlindungan Hukum Pasien Dalam Pelayanan Kesehatan Di Ruang Rawat Inap RSUD dr. Slamet Garut, dapat diambil kesimpulan bahwa sebagian besar dari responden perlindungan hukum terpenuhi, dan hampir setengahnya responden Tidak terpenuhi. hal ini menunjukan bahwa perlindungan hukum terhadap pasien termasuk didalamnya hakhak pasien sudah terlaksana dengan cukup baik sesuai dengan peraturan perundangundangan yang berlaku.

\section{Saran}

Bagi pihak rumah sakit untuk lebih meningkatkan aspek perlindungan hukum terhadap pasien yang diberikan oleh rumah sakit yaitu dengan meningkatkan hak-hak pasien. dalam upaya mendukung peningkatan kualitas pelayanan kesehatan serta lebih hati-hati, professional dan 
bertanggung jawab dalam menjalankan tugas dan profesinya. Sehingga perlindungan hukum pasien dapat sepenuhnya terpenuhi.

1, 2 Sekolah Tinggi Ilmu Kesehatan Karsa Husada Garut

Email: andhikalperceka@gmail.com

\section{DAFTAR PUSTAKA}

Black, H. K. and Black, H. K. (2018) 'Social Suffering', in Soul Pain. doi: 10.4324/9781315223698-5.

Indonesia, K. K. R. (2016) Pedoman Umum Program Indonesia Sehat dengan Pendekatan Keluarga, Sekretariat Jendral Kementeria Kesehatan RI.

Kep, S., Kep, M. and Purdiyani BagianPendidikan Kesehatan dan Ilmu Perilaku, F. (2015) 'DALAM PENINGKATAN DERAJAT KESEHATAN MASYARAKAT MENUJU MDGs 2015 Di susun oleh: UNIVERSITAS SRIWIJAYA TAHUN 2012', JURNAL KESEHATAN MASYARAKAT (eJournal).

Nasution, A. (2017) 'Sekilas Hukum Perlindungan Konsumen', Jurnal Hukum \& Pembangunan. doi: 10.21143/jhp.vol16.no6.1231.

Ni Luh Gede Yogi Arthani, S.H., M.H., Made Emy Andayani Citra, S.H., M. H. (2013) 'Perlindungan hukum bagi pasien selaku konsumen jasa pelayanan kesehatan yang mengalami malpraktek', Jurnal Advokasi FH UNMAS.

Nurdin, M. (2015) PERLINDUNGAN HUKUM TERHADAP PASIEN ATAS KORBAN MALPRAKTEK KEDOKTERAN, Jurnal Hukum Samudra Keadilan.
Nuryaasiinta, C. M. W. (2019) 'Perlindungan Konsumen Bagi Pasien Selaku Pemanfaat Pelayanan Medis', Kanun : Jurnal Ilmu Hukum. doi: 10.24815/kanun.v21i1.12812.

Perceka, A. (2018) 'Hubungan Perencanaan dan Pengarahan Kepala Ruangan

Dengan Motivasi Kerja Perawat di RS Pameungpeuk Garut Tahun 2017', Jurnal Ilmiah Administrasi Publik. doi: 10.21776/ub.jiap.2018.004.01.9.

Pohan, I. S. (2015) 'Jaminan Mutu Pelayanan Kesehatan', in Manajemen Administrasi Rumah Sakit.

Presiden RI (2009) 'UU RI No 36 Tentang Kesehatan', UU RI No 362009.

Sibarani, S. (2017) 'ASPEK PERLINDUNGAN HUKUM PASIEN KORBAN MALPRAKTIK DILIHAT DARI SUDUT PANDANG HUKUM DI INDONESIA', Justitia et Pax. doi: 10.24002/jep.v33i1.1417.

Siringoringo, V. M. P., Hendrawati, D. and Suharto, R. (2017) 'Pengaturan Perlindungan Hukum Hak-Hak Pasien Dalam Peraturan PerundangUndangan Tentang Kesehatan Di Indonesia', Diponegoro Law Journal.

Syafruddin, S. and Anand, G. (2015) 'Urgensi Informed Consent terhadap Perlindungan Hak-hak Pasien', Hasanuddin Law Review. doi: 10.20956/halrev.v1n2.89.

Undang-Undang Republik Indonesia Nomor 44 (2009) Undang-Undang Republik Indonesia Nomor 44 Tahun 2009, Tentang Rumah Sakit.

WHO (2010) Health - United Nations Sustainable Development, WHO. 